\title{
AN APPROXIMATION OF DEFLECTION LINE FUNCTION AT THE ROD LOADED BY BUCKLING UNDER SELF-WEIGHT
}

\author{
Željko Rosandić, Stanislav Kotšmíd, Pavel Beňo, Marián Minárik
}

Preliminary notes

The paper deals with an approximation of the exact deflection line function at a rod loaded by self-weight buckling via the function, which is bestpresented by the exact shape of this rod. In this paper, we suggest the methods of derivation of the critical buckling length by the exact solution and by the energy method. For the substitute functions of deflection line, the variants of goniometric functions and polynomials are chosen. Individual coefficients of the functions are chosen on the basis of existing boundary conditions and in the case of their insufficient count, they are chosen in order to express the exact rod deflection line shape in the most suitable way, which was transposed from the concrete example solution by SolidWorks Simulation software. The paper shows the errors of critical buckling length calculation against the exact solution, as well as the maximum absolute and relative deviations in the lateral displacement for the chosen function. From the individual substitute functions, one function that meets the condition for general use and has the lowest deviations from the exact solution, is subsequently chosen.

Keywords: approximation of function; buckling; polynomials; self-weight

Aproksimacija funkcije linije otklona za štap opterećen izvijanjem pod vlastitom težinom

Prethodno priopćenje

Rad se bavi aproksimacijom točne funkcije linije otklona za štap opterećen izvijanjem zbog vlastite težine pomoću funkcije, što je najbolje prikazano točnim oblikom ovog štapa. U ovom radu predlažemo metode derivacije kritične duljine izvijanja pomoću točnog rješenja i pomoću metode energije. Za zamjenske funkcije linije otklona su izabrane varijante goniometrijskih funkcija i polinomi. Pojedinačni koeficijenti funkcija su izabrani na temelju postojećih rubnih uvjeta i u slučaju nedovoljnog broja, oni su izabrani kako bi se izrazio točan oblik linije otklona štapa na najprikladniji način, koji je prenesen iz konkretnog primjera rješenja pomoću softvera SolidWorks. Rad prikazuje pogreške kritičnog izračuna duljine izvijanja nasuprot točnom rješenju, kao i maksimalna apsolutna i relativna odstupanja kod bočnog pomicanja za odabranu funkciju. Od pojedinačnih zamjenskih funkcija je naknadno izabrana ona koja ispunjava uvjet za opće korištenje i ima najmanja odstupanja od točnog rješenja.

Ključne riječi: aproksimacija funkcije; izvijanje; polinomi; vlastita težina

\section{Introduction}

The stability loss of constructional components undoubtedly belongs to the important problems in constructional mechanics. Therefore, the knowledge of stability analyses in the theoretical and computational branch is required in more detail today $[1,2]$. At present, when the effort about design of the construction with a low mass dominates, the rods with a high slenderness, which have a tendency to succumb in stability loss, often appear in practice.

Probably the most important asset into this branch was brought by Leonard Euler, who was the first one to research the case of the indifferent status in the year 1744 [1]. Euler derived equations for critical buckling force of prismatic, centric compressed rod at the different clamping from approximate differential equation of deflection line. These equations give the answer to the question how high the force applied on the rod can be, in order not to exceed the status of indifferent equilibrium. In these equations, the self-weight of rod is neglected. From logical considerations, it is obvious that the selfweight cannot be neglected with the relatively very tall rod. There is another question of how tall a rod can be not to get into the indifferent equilibrium by self-weight.

The first one, who brought a solution to this problem, was Greenhill in the year 1881 [3]. This problem was partially inspired by nature, e.g. when the people ask a question, how maximum a tree can be tall, in order not to fall due to self-weight [4]. The similar questions appeared at sighting of plants [5]. At present, there exist the equations derived by more authors for the critical buckling length at different types of clamping. The consideration of self-weight is important for the drilling rod on oil platforms, where, except for weight, the force effects operate possibly at the chimneys and towers used for electrical energy production [6].

To solve exactly the differential equation for this type of rod, the extensive knowledge of the Bessel functions theory, moreover, the function of the rod displacement in a complicated shape, is required. In this paper, the approximation of exact solution at the clamped rod with a free end is shown using the energy method, where the function of deflection line was substituted by some variants of goniometric functions and polynomials. By these approximations, the approximate critical buckling length of the rod and approximate values of its lateral displacement were derived. In dependence on the character of this problem, the coefficients of functions were derived. In the paper, the deviation from the exact solution (for which the output from SolidWorks Simulation software was considered) is subsequently shown.

\section{Exact solution to the problem}

A general differential Eq. (1) for the clamped prismatic rod with a free end and length $l$ loaded by selfweight (Fig. 1) can be, according to the literature [7], written in the form

$E J \frac{\mathrm{d}^{3} w}{\mathrm{~d} x^{3}}+\gamma(l-x) \frac{\mathrm{d} w}{\mathrm{~d} x}=0$, 
where the following boundary condition is applied

$$
w(0)=w^{\prime}(0)=w^{\prime \prime}(l)=0,
$$

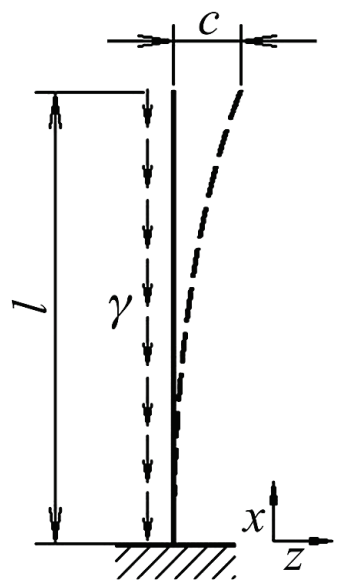

Figure 1 Buckling under self-weight

where $x$ is a distance along the rod length, $w(x)$ is the lateral displacement, $\gamma$ is the gravity force per length unit and $E J$ is the rod stiffness. A trivial solution to Eq. (1) equals zero. A non-trivial solution is a problem of the own numbers, which is presented by Love in the form [7]

$$
\begin{aligned}
& p(x)=\frac{\mathrm{d} w(x)}{\mathrm{d} x}=\left[a J_{1 / 3}(\xi)+b J_{-1 / 3}(\xi)\right] \cdot(1-x)^{\frac{1}{2}}, \\
& \xi(x)=\frac{2}{3} \sqrt{\frac{\gamma}{E J}}(1-x)^{\frac{3}{2}},
\end{aligned}
$$

where $a$ and $b$ are undetermined constants. The equation solution (1) for load according to Fig. 1 applies the expression of critical buckling length

$$
l_{\text {crit }, e}=\sqrt[3]{\frac{9 B^{2}}{4} \frac{E J}{\gamma}},
$$

where $B$ is the lowest root of the Bessel function at the first kind in order $(-1 / 3)$

$$
J_{-1 / 3}(x)=0
$$

This value is according to [8] $x \approx 1,866350859$. Eq. (5) can be written as follows

$$
l_{\text {crit }, e}=\sqrt[3]{7,837347439 \frac{E J}{\gamma}}
$$

\section{Approximation of the exact solution}

The energy method, which is used for calculating the approximate function, is based on a principle of virtual works. We can use the mathematical formulas according to literature [9], where the potential energy at constantly operated load is
$\Pi=\int_{0}^{l} \frac{1}{2} E J\left(w^{\prime \prime}\right)^{2} \mathrm{~d} x-\gamma \int_{0}^{l}\left(\int_{0}^{x} \frac{1}{2}\left(w^{\prime}\right)^{2} \mathrm{~d} x\right) \mathrm{d} x$.

For the function $w(x)$ and minimum of the potential energy for a non-trivial solution $c \neq 0$, where $c=w_{\max }$, the relations are applied [9]

$$
\begin{aligned}
& w(x) \approx c \cdot f(x), \\
& \frac{\mathrm{d} \Pi(c)}{\mathrm{d} c}=\int_{0}^{l} \frac{1}{2} E J\left(f^{\prime \prime}(x)\right)^{2} \mathrm{~d} x-\gamma \int_{0}^{l}\left(\int_{0}^{x} \frac{1}{2}\left(f^{\prime}(x)\right)^{2} \mathrm{~d} x\right) \mathrm{d} x=0, \\
& \gamma=\frac{\int_{0}^{l} E J\left(w^{\prime \prime}\right)^{2} \mathrm{~d} x}{\int_{0}^{l}\left(\int_{0}^{x}\left(w^{\prime}\right)^{2} \mathrm{~d} x\right) \mathrm{d} x} .
\end{aligned}
$$

From Eq. (11), the critical buckling length $l_{\text {crit }}$ can be derived. At the axial load of the rod by force alone, an approximate function is chosen in the following form

$$
w(x)=c \cdot\left(1-\cos \left(\frac{\pi x}{2 l}\right)\right),
$$

where the boundary conditions are met

$$
\begin{aligned}
& w(0)=0, \\
& w(l)=c, \\
& w^{\prime}(0)=0, \\
& w^{\prime \prime}(l)=0 .
\end{aligned}
$$

At the load by self-weight, the form of deflection line is not equal to the form according to Eq. (12), of course. At the beginning, let us assume that the form will exist on the basis of goniometric function. Let us assume the $m^{\text {th }}$ power of cosine function and the whole form of function in the $n^{\text {th }}$ power

$w(x)=c\left(1-\cos ^{m}\left(\frac{\pi x}{2 l}\right)\right)^{n}$

The boundary conditions (13) to (16) are still met. If we introduce $m$ and $n$ equals 1 , we get a function in the form according to Eq. (12). After the calculation of respective derivations and their application into Eq. (11), we get

$$
\gamma=\frac{\int_{0}^{l} E J\left(\frac{c \pi^{2}}{4 l^{2}} \cos \left(\frac{\pi x}{2 l}\right)\right)^{2} \mathrm{~d} x}{\int_{0}^{l}\left(\int_{0}^{x}\left(\frac{c \pi}{2 l} \sin \left(\frac{\pi x}{2 l}\right)\right)^{2} \mathrm{~d} x\right) \mathrm{d} x}
$$


Using Eq. (18), we get the critical buckling length (19) for the load according to Fig. 1

$$
l_{\mathrm{crit}, a}=\sqrt[3]{\frac{\pi^{2} E J}{\gamma\left(2-\frac{8}{\pi^{2}}\right)}}=\sqrt[3]{8,297756065 \frac{E J}{\gamma}} .
$$

Compared to the exact solution, this solution gives a higher value of critical buckling length $l_{\text {crit }}$. Let us look for $m$ and $n$, for which it will be obtained, that the difference between exactly derived $l_{\text {crit, } e}$ and approximate $l_{\text {crit, } a}$ will be kept to minimum. Solving this problem analytically is time consuming and complicated because of the derivation of antiderivative

$$
\int\left(w^{\prime}(x)^{2}\right) \mathrm{d} x
$$

which means to solve the hypergeometric function when fulfilling the concrete conditions by mathematical software. The solution can be easier by a known value of the critical buckling length, which is one of the integral borders in Eq. (11). This value is calculated by Eq. (11), of course. Therefore, we verify the results by a properly chosen value. For the beginning, there is a sufficient hypothesis that for $m$ and $n$ exists a better approximation of exact solution than in the case $m=1$ and $n=1$. The following concrete example can help us. In this example, the critical buckling length $l_{\text {crit, } e}$ was computed from the exact solution and according to the previous consideration of the unknown member at expression $E J / \gamma$ in Eq. (19) was computed. The next type of function, which can approximate the exact function, is polynomial. From mathematics, it is known that any function can be replaced by the infinity sum of polynomial members.

$$
w(x)=c \cdot \sum_{i=0}^{\infty} a_{i} x^{i}
$$

Practically, this polynomial cannot be created. However, we can restrict ourselves to polynomials of small degrees, and in our case the second and the sixth degree. After the calculation of respective derivations and their application into Eq. (11), we get

$$
\gamma=\frac{\int_{0}^{l} E J\left\{c \cdot \sum_{i=2}^{k}\left[i(i-1) a_{i} x^{i-2}\right]\right\}^{2} d x}{\int_{0}^{l} \int_{0}^{x}\left\{c \cdot \sum_{i=1}^{k}\left[i a_{i} x^{i-1}\right]\right\}^{2} d x d x} .
$$

\section{Comparison of Software and Approximate Solution}

Individual coefficients of polynomials and exponents $m$ and $n$ were derived for the concrete example by the least squares method. For the exact values, there were chosen data from the strain analysis by SolidWorks Simulation software for steel circle rod with density $\rho=$ $7850 \mathrm{~kg} \cdot \mathrm{m}^{-3}$, modulus of elasticity $E=2,1 \times 10^{11} \mathrm{~Pa}$ and diameter $d=0,01 \mathrm{~m}$. With consideration of gravity acceleration value $g=9,81 \mathrm{~m} \cdot \mathrm{s}^{-2}$, the critical buckling length has a value $l_{\text {crit }, e}=5,111832123 \mathrm{~m}$. The overview of created residuum and $l_{\text {crit }}$ for the individual approximate function is shown in Tab. 1. Two methods of approximation were investigated. The first one is at the boundary condition met according to Eq. (13) to (16). From a character of the task, it is obvious that the polynomial of the $2^{\text {nd }}$ degree cannot meet the condition (16), and therefore it was neglected. The second method

\begin{tabular}{|c|c|c|c|c|c|c|}
\hline & \multicolumn{3}{|c|}{ Met boundary conditions } & \multicolumn{3}{|c|}{ Unused boundary conditions } \\
\hline Approximation & $\begin{array}{l}\text { Residuum } \\
\text { res / - }\end{array}$ & $\begin{array}{l}\text { Critical buckling } \\
\text { length } l_{\text {crit }} / \mathrm{m}\end{array}$ & $\begin{array}{c}\text { Accuracy } l_{\text {crit }} \\
\varepsilon / \%\end{array}$ & $\begin{array}{l}\text { Residuum } \\
\text { res / - }\end{array}$ & $\begin{array}{l}\text { Critical buckling } \\
\text { length } l_{\text {crit }} / \mathrm{m}\end{array}$ & $\begin{array}{c}\text { Accuracy } l_{\text {crit }} \\
\varepsilon / \%\end{array}$ \\
\hline$c \cdot\left(\cos ^{m}(\pi x / 2 l)\right)$ & 0,003555582 & unsolved & unsolved & - & - & - \\
\hline$c \cdot(\cos (\pi x / 2 l))^{n}$ & 0,001134074 & unsolved & unsolved & - & - & - \\
\hline$c \cdot\left(\cos ^{m}(\pi x / 2 l)\right)^{n}$ & 0,000347891 & unsolved & unsolved & - & - & - \\
\hline $2^{\text {nd }}$ dg. polynomial & 0,216913815 & 5,891791 & 84,742097 & 0,009456603 & 3,881022 & 75,922319 \\
\hline $3^{\text {rd }}$ dg. polynomial & 0,011590640 & 5,144786 & 99,355335 & 0,000027855 & 5,163995 & 98,979568 \\
\hline $4^{\text {th }}$ dg. polynomial & 0,000423588 & 5,122977 & 99,781985 & 0,000008459 & 5,271360 & 96,879237 \\
\hline $5^{\text {th }}$ dg. polynomial & 0,000003004 & 5,112182 & 99,993149 & 0,000000126 & 8,837474 & 27,117278 \\
\hline $6^{\text {th }}$ dg. polynomial & 0,000000003 & 5,111833 & 99,999987 & 0,000000002 & 5,110308 & 99,970175 \\
\hline
\end{tabular}
was approximation by functions, where boundary conditions (13) to (16) were not taken into account.

Table 1 A dependence of residuums and critical buckling lengths on used approximate functions

For the used variants of goniometric functions, both exponents $m$ and $n$ are chosen values, for the polynomials are some coefficients obtained from boundary conditions and others are chosen values. These values were computed for the concrete rod parameters. For other parameters, they do not have a value of notice and computed displacement by these functions will not be equal to the exact values. Due to having only four boundary conditions, we can determine only four coefficients so that they are a function of the critical buckling length $l_{\text {crit, } e}$. In Tab. 2, the short shapes of polynomials which suit the previous consideration for different materials and rod diameters are shown. According to (13) and (15), the coefficients at linear and absolute members equal zero.

The residuals at the cubic polynomial $a_{3} \cdot x^{3}+a_{2} \cdot x^{2}$ are the lowest. The approximation by the cubic polynomial is shown in Fig. 2, where behaviour of three different materials (steel, aluminium, copper) for $d=0,01 \mathrm{~m}$ is shown. This analysis was made for dimensions $d=0,05 \mathrm{~m}$ and $d=0,005 \mathrm{~m}$ too, but graphical outputs have a very similar behaviour, and therefore they are not shown. 
Table 2 The overview of the residuals for individual polynomial shapes, materials and rod dimensions

\begin{tabular}{|c|c|c|c|c|c|c|c|c|c|}
\hline \multirow{2}{*}{$\begin{array}{l}\text { Polynomial } \\
\text { shape }\end{array}$} & \multicolumn{3}{|c|}{$\begin{array}{c}\text { Steel } \\
\left(E=210 \mathrm{GPa} ; \rho=7850 \mathrm{~kg} \cdot \mathrm{m}^{-3}\right)\end{array}$} & \multicolumn{3}{|c|}{$\begin{array}{c}\text { Aluminium } \\
\left(E=70 \mathrm{GPa} ; \rho=2700 \mathrm{~kg} \cdot \mathrm{m}^{-3}\right)\end{array}$} & \multicolumn{3}{|c|}{$\begin{array}{c}\text { Copper } \\
\left(E=110 \mathrm{GPa} ; \rho=8940 \mathrm{~kg} \cdot \mathrm{m}^{-3}\right)\end{array}$} \\
\hline & $d=0,005 \mathrm{~m}$ & $d=0,01 \mathrm{~m}$ & $d=0,05 \mathrm{~m}$ & $d=0,005 \mathrm{~m}$ & $d=0,01 \mathrm{~m}$ & $d=0,05 \mathrm{~m}$ & $d=0,005 \mathrm{~m}$ & $d=0,01 \mathrm{~m}$ & $d=0,05 \mathrm{~m}$ \\
\hline$a_{3} \cdot x^{3}+a_{2} \cdot x^{2}$ & 0,0036 & 0,0009 & 0,00004 & 0,0106 & 0,0027 & 0,0001 & 0,0032 & 0,0008 & 0,00003 \\
\hline$a_{4} \cdot x^{4}+a_{2} \cdot x^{2}$ & 0,0172 & 0,0043 & 0,0002 & 0,0501 & 0,0125 & 0,0005 & 0,0152 & 0,0038 & 0,0002 \\
\hline$a_{4} \cdot x^{4}+a_{3} \cdot x^{3}$ & 0,1740 & 0,0433 & 0,0017 & 0,5051 & 0,1262 & 0,0050 & 0,1533 & 0,0382 & 0,0015 \\
\hline$a_{5} \cdot x^{5}+a_{2} \cdot x^{2}$ & 0,0292 & 0,0073 & 0,0003 & 0,0848 & 0,0212 & 0,0008 & 0,0258 & 0,0064 & 0,0003 \\
\hline$a_{5} \cdot x^{5}+a_{3} \cdot x^{3}$ & 0,2380 & 0,0592 & 0,0024 & 0,6905 & 0,1725 & 0,0069 & 0,2096 & 0,0522 & 0,0021 \\
\hline$a_{5} \cdot x^{5}+a_{4} \cdot x^{4}$ & 0,4433 & 0,1103 & 0,0044 & 1,2861 & 0,3213 & 0,0128 & 0,3905 & 0,0972 & 0,0039 \\
\hline$a_{6} \cdot x^{6}+a_{2} \cdot x^{2}$ & 0,0380 & 0,0095 & 0,0004 & 0,1104 & 0,0276 & 0,0011 & 0,0335 & 0,0084 & 0,0003 \\
\hline$a_{6} \cdot x^{6}+a_{3} \cdot x^{3}$ & 0,2833 & 0,0705 & 0,0028 & 0,8220 & 0,2054 & 0,0082 & 0,2495 & 0,0621 & 0,0025 \\
\hline$a_{6} \cdot x^{6}+a_{4} \cdot x^{4}$ & 0,5274 & 0,1312 & 0,0053 & 1,5299 & 0,3822 & 0,0153 & 0,4646 & 0,1156 & 0,0046 \\
\hline$a_{6} \cdot x^{6}+a_{5} \cdot x^{5}$ & 0,7197 & 0,1789 & 0,0072 & 2,0876 & 0,5216 & 0,0209 & 0,6341 & 0,1578 & 0,0063 \\
\hline
\end{tabular}

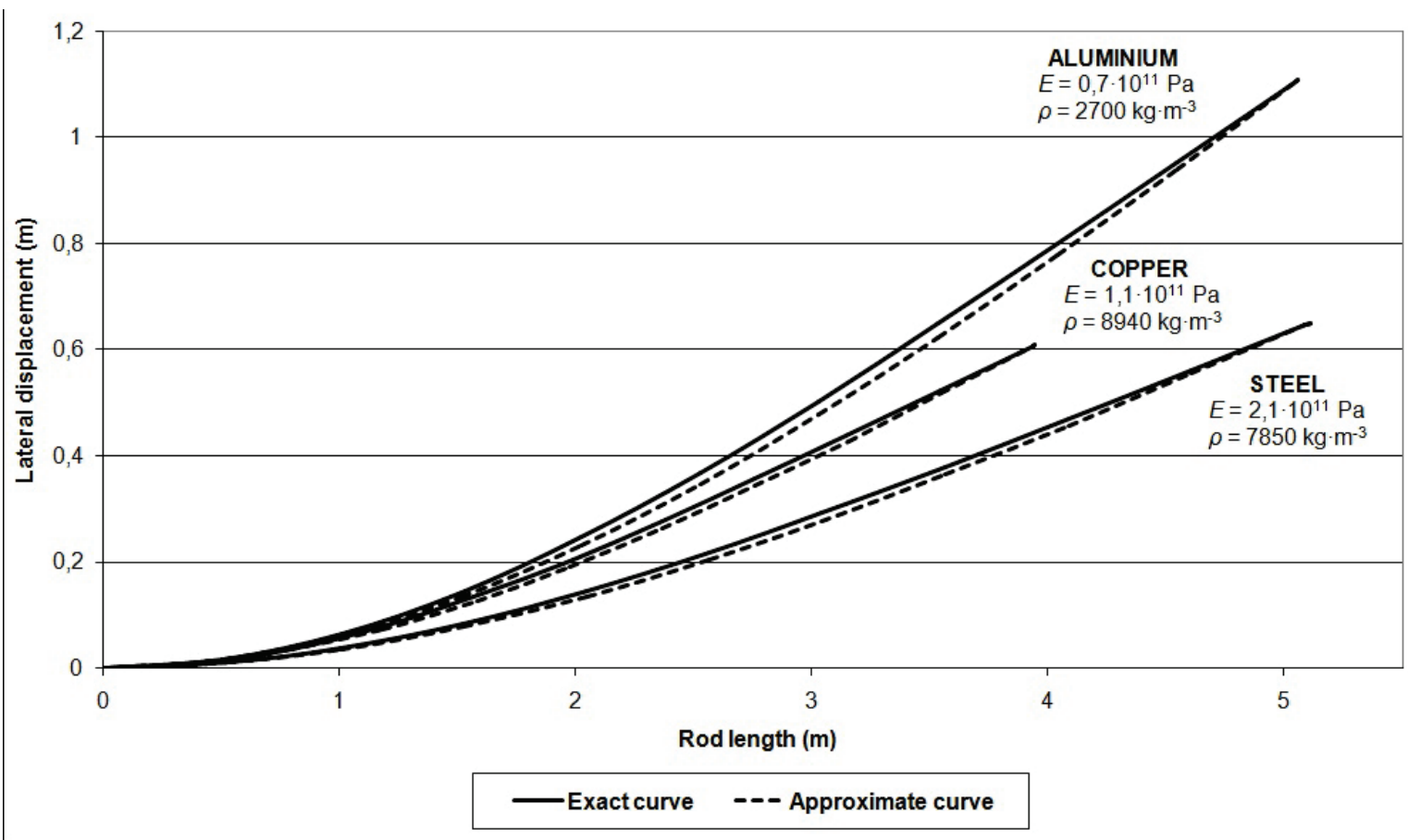

Figure 2 Comparison of the exact and approximate curves of three materials for $d=0,01 \mathrm{~m}$

\section{Results and discussion}

As we can see from Tab. 1, in the case of approximation by cosine function at presented variants, the lowest value of residuals is at the function with the $m^{\text {th }}$ and the $n^{\text {th }}$ power, namely 0,0003. In the case of polynomials we can see, with an increase of the degree, the residuum is lower, which means the approximation of the exact shape is better. Comparing the met and unused boundary conditions, residual values are lower in the second case. On the other hand, the values of the critical buckling length are more stable and accurate when meeting the boundary conditions.

At the goniometric functions, we could not derive the equations of the critical buckling length because of complications with derivation of Eq. (20). The lateral displacement was determined in 129 points along the rod length. Maximum dilatation of this shape from the exact value is culminated from $0,021845 \mathrm{~m}$ at the $2^{\text {nd }}$ degree polynomial to $8,5 \times 10^{-9} \mathrm{~m}$ at the $6^{\text {th }}$ degree polynomial. With an increase of polynomial degree, the accuracy of $l_{\text {crit, } a}$ also increases. At the $2^{\text {nd }}$ degree polynomial, we get the accuracy value $l_{\text {crit, } a} 84,74 \%$, at the $6^{\text {th }}$ degree polynomial, it is almost $100 \%$.
As it was mentioned before, the values of coefficients were mostly chosen according to the concrete rod parameters. For other parameters, these coefficients do not have a value of notice and computed displacements by these functions will not have a good approximation. We can clearly say the coefficients are functions of the critical

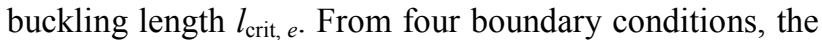
polynomials can have maximum four coefficients. From Tab. 2, we can compare the created residuals for ten proposed functions which meet all boundary conditions. The functions were investigated for three different diameters and materials with different modulus of elasticity and density. As it can be seen, the lowest residual values appear at the $3^{\text {rd }}$ degree polynomial.

The purpose of the following investigation was to determine to which extent this approximation by this polynomial is usable. In ten points, in which the analysis of dilatation was made, the maximum displacement from the exact value was determined. Its value culminates in dependence on the material and geometrical characteristics. A displacement and the residuum decrease with an increase of the rod diameter and material density. The maximum absolute dilatation achieves the values from $0,002832 \mathrm{~m}$ on the copper rod and diameter $d=0,05$ 
$\mathrm{m}$ to $0,050804 \mathrm{~m}$ on the aluminium rod and diameter $d=$ $0,005 \mathrm{~m}$. The shapes of exact and approximate function can be seen in Fig. 2, where three different rod materials at diameter $d=0,01 \mathrm{~m}$ are shown. The shapes are similar for other diameter values. However, absolute dilatations do not show the use of this approximation. The maximum relative dilatation is around $5 \%$ value for all investigated rods, which is acceptable in practical calculation. The approximate function of the rod deflection line for the case according to Fig. 1 can be chosen in the form (23)

$$
w(x)=c \cdot\left(-\frac{1}{2 l^{3}} x^{3}+\frac{3}{2 l^{2}} x^{2}\right) .
$$

\section{Conclusion}

The aim of this paper was to find the function of rod deflection line loaded by buckling under self-weight so that it approximates the exact shape best. The analytical solution to this problem is complicated, therefore the energy method was chosen for the expression of an approximate solution. Three variants of the goniometric function and five types of polynomials were taken into consideration.

According to Tab. 1, it can be seen that with an increase of the polynomial degree, the accuracy of curve approximation increases. Most of the coefficients have to be chosen to the concrete rod type, of course. If the coefficients were a function of the critical buckling length only, maximum four coefficients can appear at the approximate function. More variants of these polynomials can be created. The lowest residuals appear at the full cubic polynomial.

As it can be seen from investigated materials, the relative dilatations for individual investigated values are situated around $5 \%$ value, which is acceptable for practice. The approximate function of the rod deflection line can be chosen with a sufficient accuracy in shape (23), where only maximal displacement $c$ appears as only one unknown member, for whose determination of an approximate equation can be created after meeting certain conditions.

Solving the issues points at other tasks which can be studied and solved for complex development of buckling theory when loading by self-weight, for solving suitable choice of needed coefficient methodology, for possibilities of using for combined strain and, of course, applicability in the non-linear branch, and last but not least, to connect the theory with practice.

\section{References}

[1] Wei, D. J.; Yan, S. X.; Zhang, Z. P.; Li, X. F. Critical load for buckling of non-prismatic columns under self-weight and tip force. // Mechanics Research Communications. 37, 6(2010), pp. 554-558. DOl: 10.1016/j.mechrescom.2010.07.024

[2] Eryilmaz, A.; Atay M. T.; Coskun, S. B.; Basbük, M. Buckling of Euler columns with a continuous elastic restraint via homotopy analysis method. // Journal of Applied Mathematics. http://www.hindawi.com/journals/ jam/2013/341063. (10.01.2014)
[3] Duan, W. H.; Wang, C. M. Exact solution for buckling of columns including self-weight. // Journal of Engineering Mechanics. 134, 1(2008), pp. 116-119. DOI: 10.1061/(ASCE)0733-9399(2008)134:1(116)

[4] Peltola, H. M. Mechanical stability of trees under static loads. // American Journal of Botany. 93, 10(2006), pp. 1501-1511. DOI: 10.3732/ajb.93.10.1501

[5] Freaner, F. M.; Ojanguren, C. T.; Niklas, K. J. Stem biomechanics of three columnar cacti from the Sonoran desert. // American Journal of Botany. 85, 8(1998), pp. 1082-1090. DOI: $10.2307 / 2446341$

[6] Aydogan, O. Buckling of heavy bars. // Mathematical \& Computational Applications. 1, 2(1996), pp. 93-99.

[7] Sampaio, J. H. B.; Hundhausen, J. R. A mathematical model and analytical solution for buckling of inclined beam-columns. // Applied Mathematical Modelling. 22, 6(1998), pp. 405-421. DOI: 10.1016/S0307$904 \times(98) 10014-8$

[8] Cox, S. J.; McCarthy, C. M. The shape of the tallest column. // SIAM Journal of Mathematical Analysis. 29, 3(1998), pp. 547-554. DOI: 10.1137/S0036141097314537

[9] Govindjee, S. Engineering Mechanics of Deformable Solids: A Presentation with Exercises. Oxford University Press, Oxford, 2013.

\section{Authors' addresses}

Željko Rosandić, B.Sc.

Mechanical Engineering Faculty in Slavonski Brod

J. J. Strossmayer University of Osijek

Trg Ivane Brlić Mažuranić 2

HR-35000 Slavonski Brod, Croatia

E-mail: zrosandi@sfsb.hr

\section{Stanislav Kotšmíd, M.Sc.}

Faculty of Environmental and Manufacturing Technology

Technical University in Zvolen

Študentská 26

96001 Zvolen, Slovak Republic

E-mail: stanislav.kotsmid@gmail.com

Pavel Beňo, Associate Professor Ph.D.

Faculty of Environmental and Manufacturing Technology

Technical University in Zvolen

Študentská 26

96001 Zvolen, Slovak Republic

E-mail: beno@tuzvo.sk

\section{Marián Minárik, Ph.D.}

Faculty of Environmental and Manufacturing Technology Technical University in Zvolen

Študentská 26

96001 Zvolen, Slovak Republic

E-mail:minarik@tuzvo.sk 